providing technical assistance services for Arab economic and social development.

Members. Algeria, Bahrain, Djibouti, Egypt, Iraq, Jordan, Kuwait, Lebanon, Libya, Mauritania, Morocco, Oman, Palestine, Qatar, Saudi Arabia, Somalia, Sudan, Syria, Tunisia, United Arab Emirates, Republic of Yemen.

Headquarters: PO Box 21923, Safat 13080, Kuwait.

Website: http://www.arabfund.org

Director General and Chairman of the Board of Directors:

Abdulatif Y. al-Hamad (Kuwait).

\section{Arab Monetary Fund (AMF)}

Origin. The Agreement establishing the Arab Monetary Fund was approved by the Economic Council of the League of Arab States in April 1976 and the first meeting of the Board of Governors was held on 19 April 1977.

Aims. To assist member countries in eliminating payments and trade restrictions, in achieving exchange rate stability, in developing capital markets and in correcting payments imbalances through the extension of short- and medium-term loans; the co-ordination of monetary policies of member countries; and the liberalization and promotion of trade and payments, as well as the encouragement of capital flows among member countries.

Members. Algeria, Bahrain, Comoros, Djibouti, Egypt, Iraq, Jordan, Kuwait, Lebanon, Libya, Mauritania, Morocco, Oman, Palestine, Qatar, Saudi Arabia, Somalia, Sudan, Syria, Tunisia, United Arab Emirates, Republic of Yemen.

Headquarters: PO Box 2818, Abu Dhabi, United Arab Emirates. Website: http://www.amf.org.ae

Director General and Chairman of the Board of Directors:

Dr Abdulrahman al-Hamidy (Saudi Arabia).

\section{Arab Organization for Agricultural Development (AOAD)}

The AOAD was established in 1970 and commenced operations in 1972. Its aims are to develop natural and human resources in the agricultural sector and improve the means and methods of exploiting these resources on scientific bases; to increase agricultural productive efficiency and achieve agricultural integration between the Arab States and countries; to increase agricultural production with a view to achieving a higher degree of self-sufficiency; to facilitate the exchange of agricultural products between the Arab States and countries; to enhance the establishment of agricultural ventures and industries; and to increase the standards of living of the labour force engaged in the agricultural sector.

Organization. The structure comprises a General Assembly consisting of ministers of agriculture of the member states, an Executive Council, a Secretariat General, seven technical departments-Food Security, Human Resources Development, Water Resources, Studies and Research, Projects Execution, Technical Scientific Co-operation, and Financial Administrative Department-and two centres-the Arab Center for Agricultural Information and Documentation, and the Arab Bureau for Consultation and Implementation of Agricultural Projects.
Members. Algeria, Bahrain, Comoros, Djibouti, Egypt, Iraq, Jordan, Kuwait, Lebanon, Libya, Mauritania, Morocco, Oman, Palestine, Qatar, Saudi Arabia, Somalia, Sudan, Syria*, Tunisia, United Arab Emirates, Republic of Yemen. ${ }^{*}$ Membership suspended since Nov. 2011.

Official languages: Arabic (English and French used in translated documents and correspondence).

Headquarters: Street No. 7, Box 474, Al-Amarat, Khartoum,

Sudan.

Website: http://www.aoad.org

Director General: Dr Tariq Moosa al-Zadjali (Oman).

\section{Gulf Co-operation Council (GCC)}

Origin. Also referred to as the Co-operation Council for the Arab States of the Gulf (CCASG), the Council was established on 25 May 1981 on signature of the Charter by Bahrain, Kuwait, Oman, Qatar, Saudi Arabia and the United Arab Emirates.

Aims. To assure security and stability of the region through economic and political co-operation; promote, expand and enhance economic ties on solid foundations, in the best interests of the people; co-ordinate and unify economic, financial and monetary policies, as well as commercial and industrial legislation and customs regulations; achieve self-sufficiency in basic foodstuffs.

Organization. The Supreme Council formed by the heads of member states is the highest authority. Its presidency rotates, based on the alphabetical order of the names of the member states. It holds one regular annual session in addition to a mid-year consultation session. Attached to the Supreme Council are the Commission for the Settlement of Disputes and the Consultative Commission. The Ministerial Council is formed of the Foreign Ministers of the member states or other delegated ministers and meets quarterly. The Secretariat consists of the following sectors: Political Affairs, Military Affairs, Legal Affairs, Human and Environment Affairs, Information Centre, Media Department, Gulf Standardization Organization (GSO), GCC Patent Office, Secretary-General's Office, GCC Delegation in Brussels, Technical Telecommunications Bureau in Bahrain. In Jan. 2003 it launched a customs union, introducing a 5\% duty on foreign imports across the trade bloc.

Finance. The annual budget of the GCC Secretariat is shared equally by the six member states.

Headquarters: PO Box 7153, Riyadh-11462, Saudi Arabia.

Website (Arabic only): http://www.gcc-sg.org

Secretary-General: Abdul Latif bin Rashid al-Zayani (Bahrain).

\section{Further Reading}

Twinam, J. W., The Gulf, Co-operation and the Council: an American Perspective. 1992

\section{League of Arab States}

Origin. The League of Arab States (often referred to as the Arab League) is a voluntary association of sovereign Arab states, established by a Pact signed in Cairo on 22 March 1945 by the representatives of Egypt, Iraq, Saudi Arabia, Syria, Lebanon, Jordan and Yemen. It seeks to promote closer ties among member 